\title{
EXPLANATION OF INTRINSIC AND EXTRINSIC JOB SATISFACTION VIA MIRROR MODEL
}

Çetin BEKTAŞ ${ }^{1}$
Received Date (Başvuru Tarihi): 19/06/2017

Accepted Date (Kabul Tarihi): 30/10/2017

Published Date (Yayın Tarihi): 20/12/2017

\begin{abstract}
One of the most important issues focused by managers is to ensure effectiveness and efficiency of human resources in organizations. How can effectiveness and efficiency be achieved in an organization? The answer to this question relies heavily on job satisfaction of personnel. Job satisfaction refers to the general attitude developed by the individual towards her/his job. For this reason, job satisfaction cannot be seen butfelt. This feeling depends also on working environment and environmental conditions. As an abstract concept, job satisfaction consists of many components. However, more simply, factors ensuring job satisfaction are basically divided into two groups; namely, intrinsic and extrinsic job satisfaction factors. Intrinsic factors refer to the attitude of the individual towards her/his job while the extrinsicfactors refer to the factors related to the work ing environment. When combined, these two factor groups ensure the job satisfaction of the individual. These two fundamental factor groups affect both physiological and psychological state of the individual.
\end{abstract}

Key Words: Mirror Model, Extrinsic Job Satisfaction, Intrinsic Job Satisfaction

JEL Codes: J28, J81

\section{İCSEL VE DIŞSAL İŞ DOYUMUNUN AYNA MODELİ İLE AÇIKLANMASI}

ÖZ

Yöneticilerin organizasyonda odakladı̆̆ en önemli konulardan biri, insan kaynaklarının etkinliğini ve verimliliğini săglamaktır. Etkinlik ve verimlilik bir organizasyonda nasıl să̆lanacaktır? Bu sorunun cevabı büyük ölçüde personelin iş doyumuna bağlıdır. İs doyumu ise, bireyin işine yönelik geliştirdiği genel tutumu ifade etmektedir. Bu nedenle iş doyumu somut değil, soyuttur. Diğer bir deyişle görülmez, ancak hissedilir. Bu his, genel olarak çalışma ortamına ve çevresel koşullara bağll olarak değişir. İ̧ doyumu, birçok bileşenden oluşmaktadır. Bu bileşenler literatürde temel olarak iki gruba ayrllmakta ve incelenmektedir. Bunlar; iş doyumunu sağlayan içsel ve dişsal iş doyumu faktörleri olarak ifade edilmektedir. Içsel faktörler; bireyin işine yönelik tutumunu ifade ederken, dışsal faktörler çalışma ortamıyla ilgili faktörleri ifade etmektedir. Bir diğer ifadeyle bireyin işine yönlendirilmesini sağlayan dış etkenlerdir. Söz konusu bu iki faktör bir araya getirilip, birleştirildiğinde bireyin iş tatmini săglanmaktadır. Bu iki temel faktör grubu çalışan bireyin hem fizyolojik, hem de psikolojik durumunu etkilemektedir.

Anahtar Kelimeler: Ayna Modeli, İs Tatmini, Içsel İş tatmini

JEL Kodlart: J28, J81

\footnotetext{
1 Prof.Dr., Gaziosmanpaşa University, cetinbektas24@ gmail.com $\quad$ http://orcid.org/0000-0002-4295-2136
} 


\section{INTRODUCTION}

Related literature addresses job satisfaction generally under two main titles, which are intrinsic job satisfaction and extrinsic job satisfaction. Organizational satisfaction can be achieved once both types of satisfaction are achieved within the organization. Intrinsic job satisfaction is related to individual's expectations from her/his job and reflects her/his attitude towards her/his job. Job satisfaction is associated with not only financial gains but also the socio-psychological gains brought by the job. In addition, colleagues and superiors of the personnel play an important role in personnel satisfaction. Achievement of job satisfaction will be reflected to the organization as positive outputs. In the light of the literature review, effects/reflections of intrinsic and extrinsic job satisfaction on/to the organization are explained via mirror model. As is known, mirror reflects any image directly back to it. As shown in the model, intrinsic and extrinsic motivation factors have positive effects on the organization. In other words, these factors have positive reflections on the organization. These positive outputs and reflections generally emerge as a sense of organizational citizenship, high motivation and increase in organizational learning and job satisfaction.

Extrinsic job satisfaction consists of the factors external to and affecting the individual externally. This study shows main components of both factors on a model and explains their positive reflections on the organization.

\section{JOB SATISFACTION}

Job satisfaction is an important issue for both public and private organizations and non-profit organizations. Because efficient use of production means depends on personnel efficiency. One of the most important issues which will ensure personnel efficiency is job satisfaction. Job satisfaction is an indicator of physiological and psychological health as well as emotions of the personnel. Job satisfaction brings to mind the financial gains of the job and the colleagues and working environment of the personnel (Bingöl, 1996). There is no universal definition offered for the concept of job satisfaction; however, it can be defined as an emotional response that occurs as a result of the interaction between the employees' values concerning their job and the profits they gain from their jobs (Oshagbemi, 2000). Another definition offered for job satisfaction is the general attitude of the individual towards her/his job (Jacobs\&Roodt, 2007). In addition to this, another definition (Gündüz, 2005) of job satisfaction is the personal evaluation of the working conditions or the results obtained and emotional pleasure gained from the job. Change in emotions related to the job are affected by 
material factors such as pay, premium and promotion and nonmaterial factors such as working environment, friendship relations, leadership and communication (Gonzales\&Garazo, 2006).

After discovering that while some people are satisfied with their jobs, others are not, the experts working particularly on organizational psychology have started to study on this issue. To concretize, more than 12.000 studies were published till 1990 (Pool\&Pool, 2007). Increasing number of studies has continued to be published since that time.

Definitions offered for job satisfaction have three distinctive features. These are (Baş, 2002);

- Job satisfaction is a kind of emotional reaction developed against the situations arising in the working environment. Therefore, it cannot be seen but only be felt.

- Level of job satisfaction depends on to which extent outputs meet expectations. Therefore, job satisfaction depends on environmental conditions. In other words, one who cannot find what s/he expects cannot be satisfied.

- Job satisfaction shapes the attitude of the individual towards her/his job. In other words, while having positive attitudes towards specific dimensions of the job, individuals may develop negative attitudes towards some other dimensions of the job.

Bontis and Serenko (2007) stated in their study that job satisfaction comprises of four main factors. These factors are training and development, pay satisfaction, manager satisfaction and apprehension. Job apprehension negatively affects job satisfaction. Fear of losing job or failure increases failure rate of the personnel. Personnel feeling apprehension have weakening relations with their job, colleagues and managers. Another study also underlines four factors to be important in job satisfaction. Bernal et al. (2006) set four factors of professional development, interpersonal relations, economic expectations and working conditions (Goetz et al., 2016) as the fundamental factors of job satisfaction.

In the light of the general evaluation of the previous studies, it can be suggested that it would be more appropriate and comprehensible to analyse factors effective on job satisfaction under two main titles. First title is intrinsic factors and the second title is extrinsic factors. There are many studies supporting this approach (Erdoğan, 1996). Intrinsic factors are also named as personal factors. These factors are personal traits, capabilities, knowledge level and experiences. Moreover, sense of success means one's being determinant in her/his decisions and active at her/his job (Gahan\&Abeysekera, 2009). Second title is extrinsic factors, which are dependent on the working environment. These are such factors as level of job difficulty, 
pay system, career opportunities, appropriate reward system and level of human relations. Meanwhile, extrinsic satisfaction refers to monetary and status-related gains obtained via performance of the job and friendship, fellowship and prestige to be developed in the working environment. In another study, extrinsic factors are named as "extrinsic job value" and refer to the gains introduced from outer world for the job (Wu\&Ye, 2017). These are pay, monetary rewards and working conditions. These factors are also defined as external means influencing emotions of an individual. If management utilizes these means on time, in place and at required levels, it will make positive contributions to job satisfaction. However, extrinsic factors should be utilized carefully. Extrinsic and intrinsic factors effective on job satisfaction are explained below in detail.

\subsection{Intrinsic Factors}

Intrinsic job satisfaction factors include such components as sense of success at work, relations with colleagues, job stability, customer relations and efforts to unearth one's skills. Intrinsic motivation tools are directly related to the job and results from the same. Factors such as the job itself, independence granted by the job, importance of the job for the individual, involvement in management, taking responsibility, opening space for creativity and enabling the individual to utilize her/his skills and capabilities constitute intrinsic factors. Intrinsic factors are accepted to be more influential on the personnel than the extrinsic factors (Erciş, 2010). Individuals with intrinsic satisfaction can easily undertake responsibility in the organization. And, the individuals who take responsibilities tend to make sacrifices for the organization (Xie et al., 2017).

When the factors satisfying the individual derive from the individual her/himself, this is called "intrinsic satisfaction" (Lee, 2017), which differs depending mainly on the reason of behaviour. When the reason of behaviour develops in line with the fields of interest, skills and capabilities of the individual, intrinsic satisfaction plays a bigger role. In intrinsic satisfaction, perceptions of the individual match her/his expectations and evoke the individual. In contrast, when the expectations of the individual do not match her/his perceptions, the individual will be disappointed rather than satisfied. For this reason, various duties fall both to the personnel and the manager. Duties falling to the personnel are primarily to be aware of their skills and capabilities, to know themselves and to express their expectations clearly. Duties falling to the manager are not to create any false hope for the personnel and to be realistic. By this way, personnel will be prevented from having vein expectations related to their jobs. 


\subsection{Extrinsic Factors}

When the job satisfaction elements are produced by external sources, this is called extrinsic satisfaction. Extrinsic factors leading to specific behaviours are related to the environment outside the individual. Determination, willingness and skill of the individual to be successful are not sufficient alone for job satisfaction. Environmental factors to support these factors should also be highly qualified and quantified as some elements the individuals are in need of can only be met by the external environment. These are basically a physically appropriate working environment, to be a part of a coherent team, to be appreciated by colleagues and superiors and being under a project-oriented control rather than an oppressive control. Intrinsic satisfaction can be achieved and maintained only via sufficient and efficient external means. In cases where external means remain insufficient or no longer exist, intrinsic satisfaction lowers and finally disappears. Extrinsic factors refer to adaptation of the personnel to the job via external factors. These factors are related to the goals such as receiving a reward, avoiding a punishment and improving professional career. When an individual has an interest in a job, s/he thinks that $\mathrm{s} / \mathrm{he}$ can obtain tangible or intangible gains from the concerned activity (Galie, 2008). Basically, monetary reward system, job security, relations with superiors and relations with the colleagues constitute external reward system (Panagiotis\&Petridou, 2008). Significant duties fall to the leader in ensuring extrinsic job satisfaction. The leader should find and utilize the best means for canalizing the personnel to the job. Theories of hierarchy of needs should be considered at this point. It is an accepted approach that the main factor which motivates people is "the needs". For this reason, the leader should define personnel needs accurately and exert efforts to meet these needs.

\section{CONCEPTS RELATED TO JOB SATISFACTION}

Job satisfaction is containing some basic behaviour. Job satisfaction and its subjects thought to be directly related to job satisfaction are explained below. Job satisfaction is related to personnel motivation, personnel turnover rate, organizational citizenship, knowledge management and high job performance. These factors are explained below.

\subsection{Job Satisfaction and Motivation}

There is a cyclical cause-effect relationship between job satisfaction and motivation. Employees with strong intrinsic motivation can take higher level of risks in relation to their jobs (Wu et al., 2008). 
Intrinsic motivation and intrinsic values are the prerequisite of both national culture and individual approach. However, no direct relation has been documented between national culture and extrinsic rewards (Gahan\&Abeysekera, 2009). Motivation plays an important role in job satisfaction of employees. While satisfied personnel contribute to improvement of organizational performance (Ahmed, 2010), unsatisfied personnel are not expected to show high performance.

Absence of job satisfaction, low success opportunity and poor encouragement create job pressure on the personnel, which results in dissatisfaction, exhaustion and high personnel turnover (Ahmed, 2010).

Job satisfaction is generally deemed a factor providing basis for and effective on motivation. It is quite hard to motivate the personnel who have low job satisfaction. Even if motivation is somehow achieved in low job satisfaction cases, it is impossible to sustain the motivation. On the other way, job dissatisfaction is one of the most important factors increasing absenteeism rate of the personal (Piyasena et al, 2017). On the contrary, job satisfaction is deemed beneficial as it results in low personnel turnover for the organization (Lu\&Gursoy, 2016). It is rather easy to motivate the personnel, who have high job satisfaction, in line with the organizational objectives and to ensure behavioural change in them (Akınc1, 2002). In conclusion, personnel who have high job satisfaction and intrinsic motivation will be highly creative (Füller, 2010). In addition, highly-motivated personnel can produce more creative ideas (Jaskyte, 2008).

\subsection{Job Satisfaction and Personnel Turnover Rate}

In an organization with low job satisfaction, significant increases have been recorded in a four-year period in specific employee problems indexes; complaints increased by $38 \%$, discipline penalties by $44 \%$ and work force turnover rate by $70 \%$ (Akınc1, 2002). Main reason behind all these problems is the dissatisfaction of the employees with their jobs. Previous studies (Porter\& Steers, 1973; Danserau et al., 1974; Cotton\& Tuttle, 1986; Trevor, 2001) on the relationship between job satisfaction and personnel turnover showed that personnel turnover rate is low in the organizations with high personnel job satisfaction. Personnel naturally tend to continue performing the jobs they are satisfied with and to seek the ways of changing the jobs or the organizations they are dissatisfied with. In other words, the generally accepted idea is that the personnel dissatisfied with their jobs will leave their jobs (Liou, 1998). When the personnel are dissatisfied with their jobs, their organizational commitment 
reduces. High number of scientific studies has been made in recent years on organizational commitment and job satisfaction (Yuosef, 2017). Individual with reduced organizational commitment will start to have communication problems with her/his colleagues and superiors. S/he will not only close her/himself to the information to be sent by her/his colleagues and superiors but also refrain from sharing her/his knowledge and experiences with her/his colleagues. Consequently, dissatisfied personnel will leave the job and result in reduced organizational motivation.

When the leaders successfully realize the factors effective on job satisfaction, both the moral of the personnel and the organizational performance will raise. By increasing job satisfaction, participatory leadership also contributes to improvement of the personnel skills related to taking responsibility. Moreover, a participatory leader ensures that the team members take better decisions and are more involved in decision-making processes (Mohanty, Chatterjee, 2017).

Under successful leadership, the personnel will canalize all their efforts to their jobs. A person is equipped with basically three types of power. These are physical power, power of thinking and power of love. Concentration of these basic powers on one single point will increase the success chance of the individual. Otherwise, absence of one of the three powers will have negative impacts on job success. An individual who likes her/his job and thinks over the developments related to her/his job cannot be successful unless s/he exerts physical effort. Similarly, an individual who works physically and pays attention to do her/his job duly cannot be successful unless s/he likes her/his job. Therefore, concerned three powers should be activated together.

\subsection{Job Satisfaction and Organizational Citizenship}

There is a close and significant relationship between job satisfaction and organizational citizenship (Foote\& Tang 2008; Williams\&Anderson, 1991). Job satisfaction has positive effects on the organizational citizenship behaviours of the personnel (Gonzales\&Garazo, 2006). Organizational citizenship behaviours refer to lending assistance to colleagues, working until late when necessary, working on the weekends, tolerating negativities of the job/workplace and being actively involved in work (Jacobs\& Roodt, 2007). Personnel who feel committed to the organization they work for can more easily adapt to their colleagues, superiors and the working environment. 
Organizational citizenship behaviour is in close relationship with the meaningfulness of the job, the authority to make individual decisions and the effect of involvement in management. Meaningfulness of the job refers to the intrinsic importance attached to the job. Individual decision-making is the emotional preference of the individual in the organization of the job. Effect of involvement in management refers to an individual's job-related strategic and managerial outputs as well as her/his operational outputs related to the job (Panagiotis\& Petridou, 2008). When the individual deems these outputs as a gain, s/he can feel her/himself as a citizen of the organization s/he is working for.

\subsection{Job Satisfaction and Knowledge Management}

Personnel satisfied with their jobs support and contribute to knowledge management activity of the organization. Knowledge sharing contributes to intrinsic and extrinsic motivation in organizations (Galie, 2008).

Personnel equipped with both hygiene and motivational factors integrate into the organization and contribute to organizational learning. According to Herzberg, there are some job factors that result in satisfaction while there are other job factors that prevent dissatisfaction. According to Herzberg's two-factor theory, the opposite of "satisfaction" is "no satisfaction" and the opposite of "dissatisfaction" is "no dissatisfaction". However, those who work for organizations which offer poorly-organized hierarchical relations, unsatisfactory pay, poor working conditions, insufficient improvement opportunities, nonobjective success assessments, no chance for individual always feel worried. The anxiety and fear they continuously feel prevent them from sharing their knowledge as knowledge is "power" in real sense. Individuals abstain from sharing their skills and knowledge with others to sustain their current power. They think that sharing knowledge with the others means creating their alternative replacements with their own hands. For this reason, it is not easy to realize knowledge management in organizations with high personnel turnover rates. For this reason, implementations aimed at achieving personnel satisfaction will also ensure success of knowledge management implementations in an organization.

\subsection{Job Satisfaction and High Job Performance}

Job satisfaction is basically shaped by such factors as pay and distribution of pay, novelty level of job, career opportunities offered by the job, contribution of the job to professional improvement, attitude of the superiors towards the personnel and friendship relations in the organization (Gibson et al.,1997). In a previous literature study (Gannon\& 
Noon, 1971, $60.7 \%$ of 168 managers were revealed to think that high job satisfaction results in high efficiency and productivity. Moreover, job satisfaction plays an important role in personnel relations and their involvement in decisions (Antoni, 2009). Personnel satisfied with their jobs try to improve efficiency on one hand and attach importance to communication and knowledge sharing with colleagues and superiors on the other. This will play an important role in improving job performance.

\section{AIM, METHOD AND MODEL OF THE PRESENT STUDY}

\subsection{Aim of the Study}

This study mainly aimed at explaining the factors of intrinsic and extrinsic job satisfaction. It also aimed to show the positive reflections of intrinsic and extrinsic satisfaction factors on organizational success via a model.

\subsection{Study Method}

This is a theoretical (hypothetic) study. Findings obtained at the end of the literature review are presented on a model. The model presented shows the intrinsic and extrinsic factors effective on job satisfaction in a visual form. Using a model to present the issue increases its importance and comprehensibleness.

\subsection{Study Model}

As a result of his inquiry about the attitudes of employees, Herzberg et al. (1959) developed two distinct lists of factors. One set of factors caused happy feelings or a good attitude within the worker, and these factors, on the whole, were task-related. The other grouping was primarily present when feelings of unhappiness or bad attitude were evident, and these factors, Herzberg claimed, were not directly related to the job itself, but to the conditions that surrounded doing that job. The first group he called motivators (job factors): recognition, achievement, possibility of growth, advancement, responsibility, works itself.

The second group Herzberg named hygiene factors (extra-job factors): salary, interpersonal relations-supervisor, interpersonal relations-subordinates, interpersonal relations-peers, supervision-technical, company policy and administration, working conditions, factors in personal life, status and job security. Motivators refer to factors intrinsic within the work itself like the recognition of a task completed. Conversely, hygienes tend to include extrinsic entities such as relations with co-workers, which do not pertain to the worker's actual job (Tietjen\&Myers, 1998). 
When a job is inherently satisfying and its incentives are directly tied to performance, the incentives will probably not change the employees' behavior; therefore, they will neither increase extrinsic motivation nor reduce intrinsic motivation. Behavior is changed in the direction of the performance-contingent incentive, it probably does so because the incentive is salient; as a result, extrinsic motivation will increase, and intrinsic motivation will decrease. Performance result in a motivational shift toward extrinsic motivation at the expense of intrinsic motivation (Kuyaas et al., 2017). As a result intrinsic motivation factors and extrinsic motivation factors directly tied to personnel performance.

The model showing the positive organizational contributions of intrinsic and extrinsic job satisfaction is presented below. The model is particularly called the "Mirror Model" as a mirror reflects any image directly back to it. Intrinsic and extrinsic job satisfaction inputs provided by the management of the organization will also be reflected as specific outputs. Main factors of organizational motivation are shown on figure.

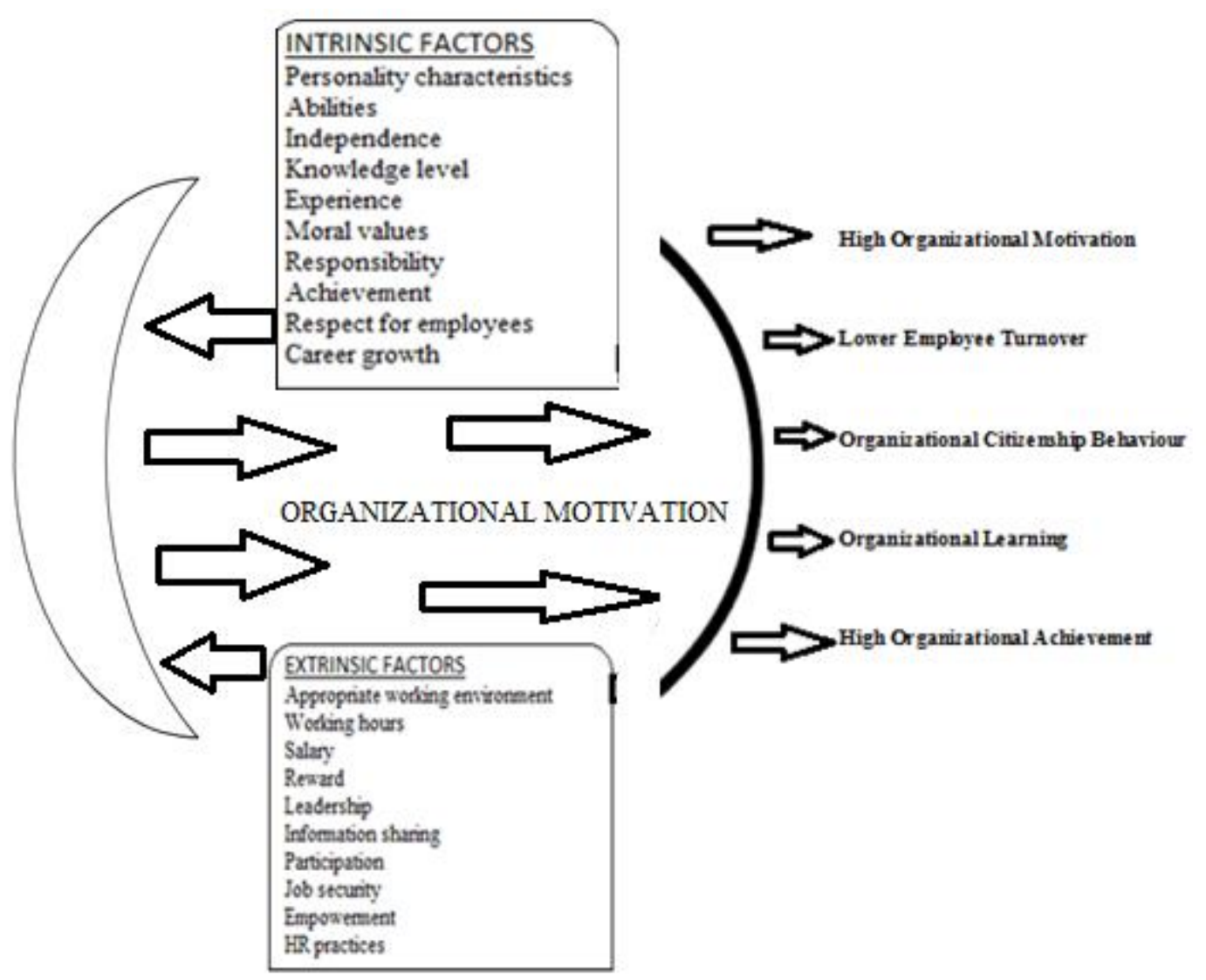

Figure 1: The Mirror Model 


\section{CONCLUSION}

This study examines how intrinsic and extrinsic motivations are reflected in organizational motivation. Because organizational motivation is result of the personnel motivation. The personnel reflect his /her positive or negative behavior like a mirror. For this reason we chose the mirror model to explain the subject. If the motivation of the staff is high, organizational motivation will also increase. Conversely, if staff motivation is low, organizational motivation will be low. In other words, staff motivation is like a mirror for showing organizational motivation.

Organizations specially focus on human resources to increase effectiveness and efficiency. They constantly seek new methods of integrating the personnel with their jobs and to enable them to be more efficient. In this scope, intrinsic and extrinsic satisfaction means play an important role in personnel satisfaction. Moreover, organizational satisfaction should be achieved for efficiency, effectiveness, profitability and sustainability in an organization. Organizational satisfaction is composed of two basic elements: intrinsic and extrinsic job satisfaction. Intrinsic job satisfaction results from personal traits of the personnel. Extrinsic job satisfaction, on the other hand, refers to the factors that come from outside the individual. These are factors such as physical working environment, material means (financial gains) and leadership behaviour and organization communication. When used together within the organization, intrinsic and extrinsic job satisfaction means produce organizational satisfaction. In other words, intrinsic and extrinsic job satisfaction means which serve as organizational inputs will produce personnel-based organizational outputs. These outputs together can be defined as organizational job satisfaction. Organizational satisfaction will offer following advantages to the organization: high personnel motivation, low personnel turnover rate, organizational citizenship behaviour, knowledge management, organizational learning and high-level organization. Eventually, personnel who are provided intrinsic and extrinsic motivation by the management will achieve high success by canalizing their muscle power, brain power and heart power altogether to their job. Modern leadership approaches should be utilized to achieve all these results. Moreover, post-modern management approaches should also be meticulously monitored and adapted to the organization. 


\section{REFERENCES}

Ahmed I., Nawaz M.M., Iqbal N., Ali M., Shaukat S., \& Usman A. (2010). Effects of Motivational Factors on Employees Job Satisfaction a Case Study of University of the Punjab, Pakistan. International Journal of Business and Management, 5(3), 70-82.

Akınc1, Z. (2002). Factors Which Affect Job Satisfaction in the Tourism Sector: a Survey in Five Star Hospitality Organizations. Akdeniz Üniversitesi İI.B.F. Dergisi, 4(1), 1-25.

Antoni, G. D. (2009). Intrinsic Extrinsic Motivations to Volunteer and Social Capital Formation. KYKLOS, 62(3), 359-370.

Baş, T. (2002). Determination of Job Satisfaction Profiles of Faculty Members. D.E.ய̈. İI.B.F. Dergisi, 17(2), 19-37.

Bernal, J.G., Castel A.G., Navarro, M.M., \& Torres P.R. (2006). Job Satisfaction: Emprical Evidence of Gender Difference. Women and Management Review, 20(4), 279-288.

Bingöl, D. (1996). Personel Yönetimi, Beta Basım Yayım, İstanbul.

Bontis, N., \& Serenko, A. (2007). The Moderating Role of Human Capital Management Practices on Employee Capabilities. Journal of Knowledge Management, 11(3), 31-51.

Cotton J.L., \& Tuttle J.M. (1986). Employee Turnover: A Meta-Analysis and Review with Implications for Research. Academy of Management Review, 11, 55-70.

Danserau, F., Cashman, J., \& Grean G. (1974). Expectancy as a Moderator of the Relationship between Job Attitudes and Turnover. Journal of Applied Psychology, 50(1), 228-237.

Erciş M. S. (2010). The Importance of Motivation in Marketing Communication and Multinational Shopping Center Example. Gazi Üniversitesi İletişim Fakültesi, 30(1), 165-180.

Erdoğan, İ. (1996). İşletme Yönetiminde Örgütsel Davranış, İstanbul Üniversitesi, İşletme Fakültesi Yayını, İstanbul.

Foote D. A., \& Tang T.P. (2008). Job satisfaction and organizational citizenship behavior (OCB): Does team commitment make a difference in self-directed teams?. Management Decision, 46(6), 933-947.

Füller, J. (2010). Refining Virtual Co-Creation from a Consumer Perspective. California Management Review, 52(2), 98-124.

Gahan P., \& Abeysekera, L., (2009). What shapes an individual's work values? An integrated model of the relationship between work values, national culture and self-construal. The International Journal of Human Resource Management, 20(1), 126-147.

Galia F. (2008). Intrinsic-Extrinsic Motivations and Knowledge Sharing in French Firms. The Icfai Journal of Knowledge Management, 6(1), 56-72.

Gannon, M. J., \& Noon, J. P. (1971). Management's critical deficiency Executives unaware of applicable research. Business Horizons, 14(1), 49-56.

Gibson, J.L., Ivancevich, J.M., \& Donnelly, J.H. (1997). Organizations, Ninth Edition, McGraw-Hill.

Goetz, K., Hasse, P., Campbell, S. M., Berger, S., Dörfer, C. E., Hahn, K., \& Szecsenyi, J. (2016). Evaluation of job satisfaction and working atmosphere of dental nurses in Germany. Community dentistry and oral epidemiology, 44(1), 24-31.

Gonzales, J.W., \& Garazo, T.G. (2006). Structural Relationships between Organizational Service Orientation, Contact Employee Job Satisfaction and Citizenship Behaviour. International Journal of Service Industry Management, 17(1), 25-50.

Gündüz, H. (2005). The Effects of Organizational Climate on Job Satisfaction and Intention to Leave: A Research. C.Ü. I.I.I.B.F. Dergisi, 6(2), 23-40.

Jacobs, E., \& Roodt, G. (2007). The Development of a Knowledge Sharing Constract tok Predict Turnover Intentions. Aslib Proceedings: New Information Perspectives, 59(3), 229-248.

Jaskyte K. (2008). Employee Creativity in U.S.and Lithuanian Nonprofit Organizations. Nonprofit Management \& Leadership, 18(4), 465-485. 
Kuvaas, B, R. B., A. W., \& G.L. Nerstad, (2017). Do intrinsic and extrinsic motivation relate differently to employee outcomes? Journal of Economic Psychology 61, 244-258.

Lee, T. J. (2017). Relationship between Intrinsic Job Satisfaction, Extrinsic Job Satisfaction, and Turnover Intentions among Internal Auditors (Doctoral dis sertation, Walden University).

Liou, K.T. (1998). Employee Turnover Intention and Professional Orientation: A Study of Detention Workers. Public Administrative Quarterly, 22(2), 161-175.

Lu, A. C. C., \& Gursoy, D. (2016). Impact of job burnout on satisfaction and turnover intention: do generational differences matter?. Journal of Hospitality \& Tourism Research, 40(2), 210-235.

Mark A., T. Robert \& M. M. (1998). Motivation and job satisfaction. Management Decision, 36 (4), $226-231$.

Mohanty, M., \& Chatterjee, M. (2017). Relationship between Demographical Variables and Leadership and Motivational Styles of Bank Managers in Kolkata. International Management Review, 13(1), 59.

Oshagbemi, T. (2000). Gender Differences in the Job Satisfaction of University. Women in Management Review, 15(7), 331-343.

Panagiotis G.P., \& Petridou E. (2008). Employees' Sychological Empowerment via Intrinsic and Extrinsic Rewards. AHCMJ, 4(1), 17-40.

Piyasena, K. G. C. C., \& Kottawatta, H. (2017). The HRM Practices on Job Satisfaction of Operational Workers in the Apparel Industry in Colombo District, Sri Lanka. Human Resource Management Journal, 3(2), 46-65.

Pool, S. \& Pool B. (2007). A Management Development Model. Journal of Management Development, 24(4), 353-369.

Porter L.\& Steers R.M. (1973). Organizational, Work, and Personal Factors in Employee Turnover and Absenteeism. Psychological Bulletin, 80(2), 161-176.

Trevor, C.O. (2001). Interactions among Actual Ease of Movement Determinants and Job Satisfaction. Academy of Management Journal, 44(4), 621-638.

Williams, L.J., \& Anderson, S.E. (1991). Job Satisfaction and Organizational Commitment as Predictors of Organizational Citizenship and In-Role Behaviors. Journal of Management, 17(3), 601-617.

Wu, H. L., Su, W. C., \& Lee, C. Y. (2008). Employee ownership motivation and individual risk-taking behavior: A cross-level analysis of Taiwan's privatized enterprises. The International Journal of Human Resource Management, 19(12), 2311-2331.

Wu, X., \& Ye, Y. (2017). A Relationship Study of Teachers' Perception towards Professional Development and Their Job Satisfaction in Guilin University of Electronic Technology, Guangxi, China. Scholar, 8(2), 165-177.

Xie, B., Zhou, W., Huang, J. L., \& Xia, M. (2017). Using goal facilitation theory to explain the relationships between calling and organization-directed citizenship behavior and job satisfaction. Journal of Vocational Behavior, 100, 78-87.

Yousef, D. A. (2017). Organizational Commitment, Job Satisfaction and Attitudes toward Organizational Change: A Study in the Local Government. International Journal of Public Administration, 40(1), 7788. 